\title{
PEMBUATAN RENCANA ANGGARAN BIAYA BAGI BADAN USAHA MILIK DESA DI KABUPATEN TANGERANG
}

\author{
Agus Sunarya Sulaeman', Taufik Raharjo*2 \\ ${ }^{1,2}$ Politeknik Keuangan Negara STAN; Jl Bintaro Utama 3A No. V, Bintaro, Ciputat Timur, \\ Tangerang Selatan, Banten, 021-7361654 \\ Program Studi D3 Kebendaharaan Negara, Jurusan Manajemen Keuangan, Politeknik Keuangan \\ Negara STAN \\ *E-mail: taufik.raharjo@pknstan.ac.id
}

\begin{abstract}
Village-owned enterprises (BUMDesa) are one of the priorities for using the Village Fund. BUMDesa was established in order to realize economic independence in rural areas. At present, all villages in Tangerang Regency have established BUMDesa, but there are still many who do not understand how to plan a budget. This business budget plan is very important in managing BUMDesa's finances. So the author discusses the need for knowledge and skills for BUMDesa managers in making budget plans to support their BUMDesa business development. The purpose of this community service activity is to increase knowledge and skills for BUMDesa managers in making budget plans for their respective businesses. This community service activity was in the form of training in making a budget plan that was followed by BUMDesa managers in the Tangerang Regency area. The result of this activity is an increase in understanding and skills in making a budget plan for their BUMDesa business.
\end{abstract}

Keywords—BUMDesa, Village, Training, Budget Plan, Community Service

\begin{abstract}
Abstrak
Badan Usaha Milik Desa (BUMDesa) merupakan salah satu prioritas penggunaan Dana Desa. BUMDesa didirikan dalam rangka mewujudkan kemandirian ekonomi di kawasan perdesaan. Saat ini, seluruh Desa di Kabupaten Tangerang telah mendirikan BUMDesa, namun masih banyak yang belum memahami bagaimana membuat rencana anggaran biaya. Rencana anggaran biaya usaha ini sangat penting dalam pengelolaan keuangan BUMDesa. Sehingga penulis memadang perlunya pengetahuan dan keterampilan bagi para pengelola BUMDesa dalam membuat rencana anggaran biaya demi mendukung pengembangan usaha BUMDesa mereka. Tujuan dari kegiatan pengabdian masyarakat ini adalah meningkatkan pengetahuan dan keterampilan bagi para pengelola BUMDesa dalam membuat rencana anggaran biaya bagi usaha mereka masing-masing. Kegiatan pengabdian masyarakat ini berupa pelatihan pembuatan rencana anggaran biaya yang diikuti oleh para pengelola BUMDesa di wilayah Kabupaten Tangerang. Hasil dari kegiatan ini adalah peningkatan pemahaman dan keterampilan dalam membuat rencana anggaran biaya bagi usaha BUMDesa mereka.
\end{abstract}

Kata kunci-BUMDesa, Desa, Pelatihan, Rencana Anggaran Biaya, Pengabdian Kepada Masyarakat

\section{PENDAHULUAN}

BUMDesa didefinisikan, dalam Peraturan Menteri Desa, Pembangunan Daerah Tertinggal, dan Transmigrasi Republik Indonesia Nomor 4 Tahun 2015, sebagai badan usaha yang seluruh atau sebagian besar modalnya dimiliki oleh desa melalui penyertaan secara langsung yang berasal dari kekayaan desa yang dipisahkan guna mengelola aset, jasa pelayanan, dan usaha lainnya untuk sebesar-besarnya kesejahteraan masyarakat Desa. BUMDesa merupakan Program dari pemerintah pusat yang dilaksanakan oleh pemerintah desa dan Badan Usaha Milik Desa (BUMDesa). Operasionalisasinya menggunakan falsafah bisnis yang berakar dari budaya lokal. Bidang usaha 
yang dijalankan berdasarkan pada potensi desa, baik potensi sumber daya alam maupun potensi sumber daya manusia.

Sebagai bentuk dukungan penuh atas program Pemerintah Pusat dalam hal ini Kementerian Desa, Pembangunan Daerah Tertinggal, dan Transmigrasi Republik Indonesia (Kemendesa PDTT), Pemerintah Kabupaten Tangerang, Provinsi Banten telah mengintruksikan pendirian BUMDesa di setiap Desa di seluruh wilayah Kabupaten Tangerang. Hasilnya saat ini seluruh Desa di Kabupaten Tangerang telah berdiri BUMDesa, karena syarat pendirian hanyalah terbitnya Peraturan Desa yang dikeluarkan oleh Pemerintah Desa, sehingga saat ini di Kabupaten Tangerang telah berdiri 246 BUMDesa.

Dari 246 BUMDesa yang telah berdiri tersebut, masih sedikit BUMDesa yang telah menjalankan usahanya. Hal ini disebabkan beberapa faktor, namun secara general faktor yang dominan adalah kurangnya kapasitas Sumber Daya Manusia (SDM) sebagai pengelola BUMDesa. Guna meningkatkan pengetahuan dan keterampilan usaha, maka pengelola-pengelola BUMDesa di Kabupatan Tangerang membuat sebuah wadah komunikasi bersama dengan nama "Forum Komunikasi BUMDesa Kabupaten Tangerang". Forum ini mencoba menjadi wadah tukar pikiran, pengalaman, dan saling memotivasi anggotanya untuk selalu memajukan BUMDesa yang dikelolanya. Dalam forum tersebut terungkap pula bahwa salah satu kendala yang dihadapi oleh pengelola BUMDesa adalah kurangnya pengetahuan dan keterampilan dalam menyusun proposal usulan usaha BUMDesa yang berisi pemetaan potensi usaha dan rencana anggaran biaya (RAB).

Menurut Nafarin [4], anggaran adalah rencana tertulis mengenai kegiatan suatu organisasi yang dinyatakan secara kuantitif dan umumnya dalam satuan uang untuk jangka waktu tertentu. Arfan [2] menyampaikan bahwa anggaran merupakan suatu rencana yang disusun secara sistematis yang meliputi seluruh kegiatan perusahaan yang dinyatakan dalam unitsatuan moneter dan berlaku untuk jangka waktu atau periode mendatang. Selanjutnya Simamora [7] anggaran merupakan suatu rencana rinci yang memperlihatkan bagaimana sumber-sumber daya diharapkan akan diperoleh dan dipakai selama periode waktu tertentu. Sedangkan Supriyono [8] berpendapat, bahwa penganggaran merupakan perencanaan keuangan perusahaan yang dipakai sebagai dasar pengendalian atau pengawasan keuangan perusahaan untuk periode yang akan datang. Anggaran merupakan suatu rencana jangka pendek yang disusun berdasarkan rencana kegiatan jangka panjang yang telah ditetapkan dalam proses penyusunan program. Menurut Sasongko dan Parulian [6], tujuan penyusunan anggaran, antara lain: 1) Perencanaan anggaran memberikan arahan bagi penyusunan tujuan dan kebijakan perusahaan; 2) Koordinasi anggaran dapat mempermudah koordinasi antarbagian-bagian di dalam perusahaan; 3) Motivasi anggaran membuat manajemen dapat menetapkan target-target tertentu yang harus dicapai oleh perusahaan; 4) Pengendalian keberadaan anggaran di perusahaan memungkinkan manajemen untuk melakukan fungsi pengendalian atas aktivitas-aktivitas yang dilaksanakan dalam perusahaan.

Biaya dapat definisikan pengorbanan sumber ekonomi, yang diukur dalam satuan uang, yang telah terjadi atau kemungkinan terjadi untuk tujuan tertentu [3]. Firdaus dan Wasilah [1] medefinikan biaya sebagai pengeluaran-pengeluaran atau nilai pengorbanan untuk memperoleh barang dan jasa yang berguna untuk masa yang akan datang atau mempunyai manfaat melebihi satu periode akuntansi tahunan.

Berdasarkan beberapa definisi anggaran dan biaya diatas, maka dapat disimpulkan bahwa $\mathrm{RAB}$ adalah segala bentuk perencanaan mengenai aktivitas-aktivitas perusahaan yang dinyatakan dalam satuan uang. RAB meliputi anggaran biaya produksi, pemasaran, biaya administrasi, dan biaya umum lainnya sehingga harus disusun secermat dan seteliti mungkin.

Sebagai tindak lanjut mencari solusi atas kendala yang dihadapi para pengelola BUMDesa di Kabupaten Tengerang maka mereka berkeinginan membuat kegiatan pelatihan penyusunan proposal usaha. Dalam merealisasikan kegiatan pelatihan penyusunan proposal usaha BUMDesa maka Forum Komunikasi BUMDesa Kabupaten Tangerang bekerjasama dengan Politeknik Keuangan Negara STAN dalam kemasan kegiatan pengabdian kepada masyarakat. Kegiatan pelatihan penyusunan proposal usaha BUMDesa berlangsung pada tanggal 10 november 2018 di aula Dinas Pemberdayaan Masyarakat dan Pemerintahan Desa (DPMPD) Kabupaten Tangerang.

Tujuan kegiatan pengabdian kepada masyarakat ini adalah menumbuhkan kesadaran para mengelola BUMDesa akan pentingnya proposal pendirian usaha BUMDesa, khususnya pentingnya RAB. Selanjutnya, kegiatan ini berupaya memberikan pengetahuan dan keterampilan dalam 
menyusun proposal pendirian usaha BUMDesa. Sasaran kegiatan ini adalah para pengelola BUMDesa di wilayah Kabupaten Tangerang, khususnya bagi pengelola BUMDesa yang baru berdiri dan belum mempunyai usaha yang pasti.

\section{METODE}

Kegiatana pengabdian kepada masyarakat ini dikemas dalam bentuk pelatihan. Pelatihan dalam kegiatan pengabdian kepada masyarakat ini bertujuan memberikan pengetahuan dan keterampilan dalam menyusun proposal pendirian usaha BUMDesa. Materi dalam pelatihan ini adalah pembuatan peta potensi usaha dan penyusunan $\mathrm{RAB}$, namun titik berat pelatihan ini pada materi penyusunan RAB. Materi Rencana Anggaran Biaya lebih diutamakan karena materi ini sangat diperlukan dalam penyusunan proposal usaha BUMDesa, karena RAB ini merupakan syarat utama dalam analisis bagi pemerintah desa sebelum pemerintah desa memberikan penyertaan modalnya di BUMDesa. Untuk pembuatan peta potensi usaha BUMDesa perlu adanya analisis yang lebih mendalam sehingga perlu observasi langsung ke lapangan.

Metode pelaksanaan kegiatan pengabdian kepada masyarakat ini dilakukan dengan tiga tahapan pelaksanaan, yaitu:

1. Persiapan,

Tahapan persiapan dilakukan dengan mengidentifikasi masalah yang dihadapi para pengelolan BUMDesa di Kabupaten Tangerang. Kegiatan berikutnya adalah koordinasi awal kegiatan dengan menentukan konsep kegiatan.

2. Penyiapan Bahan Pelatihan,

Menyusunan bahan yang diperlukan untuk pelatihan dilakukan oleh tim pengabdi dari PKN STAN, salanjutnya digandakan dan didistribusikan oleh tim Forum Komunikasi BUMDesa Kabupaten Tangerang sebagai koordinator penyelenggaraan kegiatan ini.

3. Pelaksanaan Pelatihan,

Kegiatan pelatihan penyusunan proposal usaha BUMDesa berlangsung pada tanggal 10 november 2018 di aula Dinas Pemberdayaan Masyarakat dan Pemerintahan Desa (DPMPD) Kabupaten Tangerang. Pelaksanaan kelas dipandu oleh dua pengajar utama yaitu tim pengabdi dari PKN STAN.

\section{HASIL DAN PEMBAHASAN}

Hasil pengabdian kepada masyarakat ini mendapatkan beberapa hasil yang diharapkan mempunyai efek positif dalam pengembangan BUMDesa di wilayah Kabupaten Tangerang.

\subsection{Persiapan,}

Identifikasi masalah yang dihadapi pengelola BUMDesa dilakukan melalui wawancara dengan ketua forum. Selain itu digunakan pula komunikasi lewat jaringan sosial media dengan menggunakan fasilitas WhatsApp Group. Selanjutnya dilakukan koordinasi awal kegiatan dengan menentukan konsep kegiatan, lokasi kegiatan, dan pendanaan. Konsep kegiatan diputuskan dalam bentuk pelatihan dengan tajuk "Diskusi Hasil Bursa Inovasi Desa (BID) Kabupaten Tengerang dan Pelatihan Membuat Proposal, RAB, dan LPJ". Lokasi kegiatan di aula DPMD Kabupaten Tangerang dengan alasan posisinya berada di tengah-tengah wilayah Kebupaten Tangerang. Pendanaan kegiatan ini ditangung oleh peserta karena kegiatan ini bukan termasuk program pemerintah Kabupaten, namun murni inisiatif dari Forum Komunikasi BUMDesa Kabupaten Tangerang.

\subsection{Penyiapan Bahan Pelatihan,}

Menyusunan bahan yang diperlukan untuk pelatihan dilakukan oleh tim pengabdi dari PKN STAN, selanjutnya digandakan dan didistribusikan oleh tim Forum Komunikasi BUMDesa Kabupaten Tangerang sebagai koordinator penyelenggaraan kegiatan ini. 


\subsection{Pelaksanaan Pelatihan,}

Kegiatan pelatihan penyusunan proposal usaha BUMDesa berlangsung pada tanggal 10 november 2018 di aula DPMPD Kabupaten Tangerang. Pelaksanaan kelas dipandu oleh dua pengajar utama yaitu tim pengabdi dari PKN STAN.

Materi yang disampaikan mencakup penyusunan RAB untuk jenis usaha dagang, jenis usaha jasa, dan jenis usaha produksi. Penyampaian materi diawali dengan materi penentuan harga, disampaikan bahwa penentuan harga jual dapat berdasarkan harga pasar dan dapat pula berdasarkan hitungan jumlah biaya dikeluarkan ditambah dengan laba diharapkan.

Selanjutnya materi masuk kepada materi jenis biaya. Dalam materi biaya ini disampaikan mengenai biaya-biaya yang timbul dalam usaha produksi dan usaha dagang. Selain itu disampaiakan pula materi perilaku biaya, dimana Biaya tetap (fixed cost) merupakan biaya yang tidak akan berubah secara total selama periode waktu tertentu, sekalipun terjadi perubahan yang besar atas tingkat aktivitas atau volume terkait. Selain itu ada Biaya variabel (variable cost) merupakan biaya secara total berubah seiring dengan perubahan tingkat aktivitas atau volume yang terkait. Karena pentingnya materi biaya ini, peserta diminta berdiskusi untuk mendeskripsikan biaya-biaya yang timbul dalam praktik usaha BUMDesa mereka secara detail. Setelah membahas materi biaya, maka selanjutnya dibahas mengenai titik impas.

Sebagai tambahan materi dalam pelatihan ini, disampaikan pula materi tentang konsep pembuatan laporan pertanggung jawaban BUMDesa. Materi pembuatan laporan pertanggungjawaban (LPJ) BUMDesa dirasa penting dan perlu karena setiap usaha BUMDesa harus bertanggung jawab atas segala kegiatan bisnisnya. Laporan pertanggungjawaban BUMDesa ini merupakan deskripsi material bagi apa yang telah dicapai BUMDesa.

Dalam pelatihan ini diberikan contoh sistematika LPJ yang baik. Dimana setidaknya terdapat lima $\mathrm{BAB}$ yang harus ada dalam laporan. Lima BAB itu akan menjelaskan segala sisi dari BUMDesa selama setahun mulai dari bagaimana BUMDesa lahir dan berbagai hambatan, tantangan dan peluang. BAB I berisi tentang Pendahuluan yang di dalamnya terdapat kata pengantar, daftar isi, pendahuluan, latar belakang, visi, misi, dasar hukum, dan profil BUMDesa. BAB II berisis Laporan umum, didalamnya memuat penggalian potensi, pembentukan unit usaha, dan pengertaan modal desa. BAB III berisi arah kebijakan yang telah ditempuh, dengan contoh isi kebijakan kerjasma dengan pihak ketiga, mengikuti pameran dan bazaar, menerima kunjungan, mengikuti pelatihan (sebutkan apa apa yang sudah dilakukan). BAB IV berisi tentang pelaksanaan pengelolaan, permasalahan program kerja dan keuangan, secara detail terdapat konten pelaksanaan kegiatan, permasalahan, program kerja, dan laporan keuangan (laporan laba rugi, laporan perubahan ekuitas, laporan posisi keuangan, laporan arus kas, dan catatan atas laporan keuangan. terakhir adalah BAB V, penutup, berisi kesimpulan dan harapan.
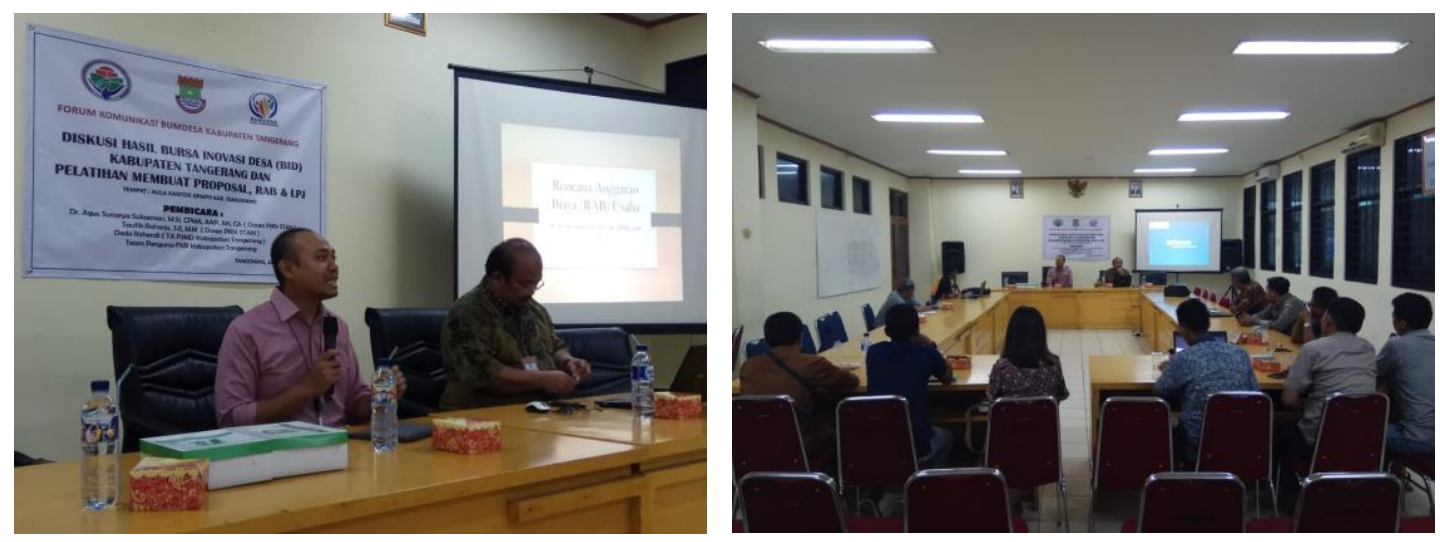

Gambar 1 Kegiatan Pelatihan

Kegiatan ini berjalan dengan lancar, namun hasil evaluasi kegiatan ini mendapatkan fakta, bahwa hanya beberapa pengelola BUMDesa yang memahami dan akan menerapkan 
pengetahuan pembuatan RAB ini. Hal ini terjadi karena latar belakang peserta pelatihan cukup heterogen, mulai dari tingkat pendidikan hingga motivasi dalam mengelola BUMDesa. Tingkat Pendidikan berpengaruh positif dalam menerimaan materi ini. Semakin tinggi tingkat Pendidikan, maka akan semakin mudah pula peserta menerima pengetahuan menganai RAB ini. Selanjutnya motivasi, pengelola dengan motivasi yang tinggi dalam dirinya untuk mengembangkan BUMDesa yang dikelolanya, lebih cenderung memperhatikan penjelasan dari pengabdi. Peserta dengan motivasi tinggi cenderung lebih aktif, terlihat dalam menyampaikan pertanyaan-pertanyaan seputar pemecahan masalah yang dihadapi dalam pengelolaan BUMDesa mereka masing-masing.

Sebagai bahan evaluasi dan mengefektifkan tujuan kegiatan kegiatan pengabdian kepada masyarakat ini, seharusnya ditindak lanjuti dengan kegiatan pengabdian kepada masyarakat dengan metode pendampingan. Pendampingan dapat dilakukan secara langsung dengan cara pengabdi terjun langsung seperti yang dilakukan oleh Yudanto [10] dalam mengembangkan produk unggulan kawasan perdesaan pada usaha berbasis komunitas Desa Cibogo. Selain itu, pendampingan dapat pula dilakukan dengan metode kombinasi antara pendampingan langsung dan tidak langsung dengan menggunakan fasilitas media sosial seperti yang dilakukan oleh Wirawan [9] dalam mendampingi pengelolaan embung desa menuju desa wisata melalui BUMK Tanjung Anom, Kabupaten Lampung Tengah. Pengabdian kepada masyarakat dengan metode kombinasi ini dilaksanakan dengan cara pendampingan langsung terlebih dahulu, selanjutnya kegiatan pendampingan dilakukan secara tidak langsung melalui aplikasi WhatsApp karena keterbatasan biaya dan waktu kunjungan. Sebagai alternatif terakhir, pendampingan dapat pula dilakukan secara tidak langsung seperti yang dilakukan oleh Raharjo [5] dalam kegiatan pendampingan optimalisasi media sosial sebagai sarana pemasaran produk, yang hanya menggunakan fasilitas WhatsApp Group.

\section{KESIMPULAN}

Setelah pelaksanaan kegiatan pengabdian kepada masyarakat ini dapat disimpulkan bahwa 1) para pengelola BUMDesa telah memahami pentingnya pendirian usaha BUMDesa. 2) melalui penyampaian materi pembuatan $\mathrm{RAB}$, para pengelola BUMDesa selaku peserta kegiatan ini telah mampu membuat RAB, namun memang tidak semua peserta mampu membuatnya dengan baik. Sehingga, setelah kegiatan pelatihan ini, perlu adanya kegiatan pendampingan kepada peserta agar ilmu yang telah diserapnya dapat dipraktikkan secara langsung dan lebih bermanfaat bagi perkembangan usaha BUMDesa mereka.

\section{SARAN}

Kegiatan pelatihan sebagai kegaitan pengabdian kepada masyarakat ini masih mempunyai banyak kekurangan. Sehingga saran-saran untuk untuk pengabdian lebih lanjut untuk menutup kekurangan pengabdian kepada masyarakat ini adalah dengan mengambangkan kegiatana pendampingan kepada peserta. Metode yang digunakan dapat disesuaikan dengan kodisi peserta maupun kondisi pengabdi.

\section{UCAPAN TERIMA KASIH}

Ucapan terimakasih kami sampaikan kepada Forum Komunikasi BUMDesa Kabupaten Tangerang karena kegiatan pengabdian ini merupakan kerjasama antara Politeknik Keuangan Negara STAN (PKN STAN) dengan Forum Komunikasi BUMDesa Kabupaten Tangerang. Bentuk dukungan Forum Komunikasi BUMDesa Kabupaten Tangerang dalam kegiatan pengabdian ini berupa pendanaan dan segala fasilitas yang sangat dibutuhkan dalam mensukseskan penyelenggraaan kegiatan ini. Semoga pelaksanaan kegaitan pengabdian ini dapat tetap terlaksana secara berkelanjutan dan membawa manfaat bagi masyarakat, khususnya bagi para pengelola BUMDesa di wilayah Kabupaten Tangerang. 


\section{DAFTAR PUSTAKA}

[1] Ahmad, Firdaus,. dan Abdullah, Wasilah, 2012. Akuntansi Biaya, Edisi 3, Salemba Empat

[2] Arfan, Lubis Ikhsan, 2011. Akuntansi Keperilakuan, cetakan kedua, Jakarta: Salemba Empat.

[3] Mulyadi, 2012. Akuntansi Biaya.Edisi ke-5, Cetakan Kesebelas, Yogyakarta: STIM YKPN.

[4] Nafarin, M, 2004. Penganggaran Perusahaan, Jakarta: Penerbit Salemba Empat.

[5] Raharjo, T., \& Prasetyo, D. H. 2018. Pendampingan Optimalisasi Media Sosial Sebagai Sarana Pemasaran Produk. Jurnal Pemberdayaan Masyarakat Madani (JPMM), No 2, Vol 2, 288-306.

[6] Sasongko, Catur dan Safrida Rumondang Parulian, 2013. Anggaran, Jakarta : Salemba Empat.

[7] Simamora, Henry, 1999. Manajemen Sumber Daya Manusia, Edisi ke-2, Cetakan Kedua, Yogyakarta: Bagian Penerbitan STIE YKPN.

[8] Supriyono, R.A., 1990. Akuntansi Biaya, Perencanaan dan Pengendalian Biayaserta Pembuatan Keputusan., edisi ke 2, Buku 2, Yogyakarta: BPFE.

[9] Wirawan, A., \& Raharjo, T, 2018. Pengelolaan Embung Desa Menuju Desa Wisata Melalui Bumk Tanjung Anom. Dinamisia: Jurnal Pengabdian Kepada Masyarakat, No 2, Vol 2, 167 174.

[10] Yudanto, A. A., Raharjo, T., \& Ubed, R. S, 2018. Pendampingan Pengembangan Produk Unggulan Kawasan Perdesaan Pada Usaha Berbasis Komunitas Desa Cibogo. Dinamisia: Jurnal Pengabdian Kepada Masyarakat, No 2, Vol 2, 161-166 